\title{
The characteristics of sea bass (Dicentrarchus labrax) eggs : description, biochemical composition and hatching performances
}

\author{
Nicole Devauchelle ${ }^{(1)}$ and Denis Coves ${ }^{(2)}$ \\ (1) IFRE.MER, Centre de Brest, B.P. $n^{\circ}$ 70, 29263 Plouzand (France). \\ (2) DEVA-SUD, Domaine de Maguelone, chemin de Mraguelone, 34250 Palatas-les-Flots (France).
}

Received July 18, 1988 ; accepted November 28 , 1988.

\begin{abstract}
This paper concerns eggs of captive fish and gonads of wild fish, from the Brittany coast obtained in the $7-18^{\circ} \mathrm{C}$ thermal range. The diameters of eggs, $1.07-1.32 \mathrm{~mm}$ are compared to those observed in other areas, especially along the Mediterranean coast. The duration of embryogenesis as a function of temperature and the efficiency of different incubators are discussed. The quality of eggs in relation with larval survival is discussed through the biochemical composition of the eggs collected in captivity compared to that of wild fish gonads. The absolute values of lipids, proteins, fatty acids, lipid classes, phosphatides and minerals measured, also the positive relations obtained between egg dry weight, diameters, mortality during incubation are presented as criteria of egg quality.
\end{abstract}

Devauchelle N., D. Coves. Aquat. Liting Resour., 1988, 1, 223-230.

Keywords : Sea Bass, Dicentrarchus labrax, eggs, embryos, aquaculture.

Caractéristiques des aufs de bar (Dicentrarchus labrax) description, composition et taux déclosion.

Résumé

Ce papier rend compte d'une étude effectuée sur les œufs de bars captifs (Dicentrarchus labrax) et des gonades de bars sauvages, collectés sur le littoral breton où la température de l'eau de mer varie de 7 à $18^{\circ} \mathrm{C}$. Les diamètres des ceufs $(1,07-1,32 \mathrm{~mm})$ sont comparés à ceux des ceufs récoltés dans d'autres sites, en particulier des sites du pourtour méditerranéen. Une relation entre durée de l'embryogenèse et température est proposée. L'efficacité de plusieurs principes d'incubation est discutece. L'étude de la qualité des coufs, en relation avec la survie larvaire est abordée à travers l'étude de la composition biochimique des oeufs pondus en bassins par comparaison à celle des gonades de poissons sauvages. Les teneurs en lipides, protéines, différentes classes de lipides, phosphatides, acides gras ct minéraux, ainsi que les relations obtenues entre poids secs, diamétres et survie des oeufs en incubation sont analysées et discutées comme pouvant ĉtre des critères de qualité des ceufs.

Mots-clés : Bar, Dicentrarchus labrax, œufs, embryons, aquaculture.

\section{INTRODUCTION}

In captivity, the period of incubation of marine fish eggs carries various different risks. For any particular species, it is necessary to know the optimal conditions for normal embryogenesis, for the geographical area in question. These factors are already well defined for sca bass, Dicentrarchus labrax, in the Mediterranean coast. Here we describe a study carricd out on this species on the Atlantic coast of France. In aquaculture, there is a widespread need to define the quality of eggs and to predict larval rearing performances. 
We looked at two parameters: (1) biometric data of eggs in relation to the water temperature and biochemical composition of eggs and ovules; (2) since rearing conditions of broodstock (social relations, food, confinement...) are unnatural, we compared wild fish gonads with early eggs from captive fish. The gonads of captive fish are less easily obtained and were not analyzed.

\section{MATERIAL AND METHODS}

Eggs naturally fertilized in tanks were spawned by sea bass [caught from the wild and adapted to captivity for 4 to 6 years in experimental facilities situated in Brittany (Devauchelle, 1986)]. They were spawned under natural or artificial temperature and light conditions $i$. $e$. during normal or out of normal spawning periods. Each batch of eggs collected over the period 1976-1983 was submitted to microscopic observations. The data obtained from aliquots (minimum $20 \mathrm{eggs}$ ) of around 300 different spawns (=egg batches from 1 female) i. e. $78 \times 10^{6} \mathrm{eggs}$ provide information on the shape, size, viability and hatching percentages of sea bass eggs.

\section{Effect of temperature on period of embryogenesis}

The experiments were conducted in an automatic incubation device described by Devauchelle ot al. (1986) and designed for small numbers of eggs (from 100 to 2000) in a total volume of $1 \mathrm{dm}^{3}$ sea water at $35 \times 10^{-3}$. The duration of embryogenesis was precisely measured at $15 \pm 0.2^{\circ} \mathrm{C}$. Its duration was also measured at $13,15,17$ and $22^{\circ} \mathrm{C}$ on three different batches of eggs from the two cell-stage to hatching. Each batch was divided into three replicates each containing 200 to 600 eggs.

Biochemical composition of eggs spawned in captivity compared to that of "wild" gonads

Samples of eggs and gonads were biochemically analyzed: five gonads from five mature wild females caught during the natural spawning period along the Brittany coast and 12 groups of morula-stage eggs of various quality obtained from normal and two out of normal spawning seasons obtained from wild sea bass adapted to captivity for 5 to 6 years. The proximal composition of eggs, lipid classes, fatty acids, phosphatidos, and minerals were estimated by techniques already described (Devauchelle et al., 1987).

\section{Relationship between egg characteristics}

Relationships between seven egg characteristics (diameter, wet weight, dry weight, water content, viability, hatching and deformity percentages were evaluated on 17 different batches of eggs issued from natural and shifted spawning seasons. The temperature of the sea water was recorded at the spawning time. The dry weight was obtained by store drying at $110^{\circ} \mathrm{C}$ for 24 hours. The viability was expressed as the percentage of eggs normally developed at morula stage to the total number of eggs collected. Hatching was the percentage of hatching eggs to viable eggs. Deformity was the percentage of deformed larvae to total hatched larvac.

\section{RESULTS}

\section{General description of eggs}

The fecund egg is pelagic, spherical and translucent. It becomes deformed by half-way through the incubation period. At maturation, the eggs contain one to five globules ( $f i g .1$ ) representing an average 2 to $3 \%$ of the total volume. Their water content is increased by an average of $25 \%$ at fertilization. A perivitelline space appears, 15 to 60 minutes post oviposition, whether or not the eggs are fertilized. The mean diameter of eggs collected at $9.5-16.5^{\circ} \mathrm{C}$, mostly at $13.15^{\circ} \mathrm{C}$, was $1.2 \mathrm{~mm}$ with $1.07 \mathrm{~mm}$ and $1.32 \mathrm{~mm}$ as minimum and maximum values. The mean variation of diameters among eggs collected over 12 years was $\pm 6 \%$. The viability percentage was estimated to be $89 \%$ and the hatching percentage from viable eggs $74 \%$. Less than $5 \%$ of the one day old larvae has skeletal deformities.

\section{Duration of embryogenesis}

Stages of embryonic development at $15^{\circ} \mathrm{C}$ are in table 1. At temperatures ranging from 13 to $22^{\circ} \mathrm{C}$, the relation between temperature $\left(\mathrm{T}^{\circ} \mathrm{C}\right)$ and the incubation duration ( $D$ in hours) was: $\mathrm{D}=414.455-119.728 \mathrm{Ln} \mathrm{T}(r=0.928)$. Between 13 and $17^{\circ} \mathrm{C}$, the development from the start of neurulation to hatching represents an average $22.4 \%$ of the total incubation duration. If temperatures changed the total duration of incubation, they did not modify the relative proportions of each stage.

\section{Biochemical composition of eggs compared to those of gonads}

The data were subjected to one way analysis of variance test. The water content was much higher in eggs than in gonads. The ash content of eggs was higher $(p<0.01)$ than that of gonads while total protcin was lower in eggs than in gonads $(p<0.01)$. Total lipid was not significantly different. However, comparison of gonads with eggs spawned out of the normal spawning season (batches 5 to 12) gave significant difference in the total lipid $(p<0.5)$ (table 2).

Lipids were mainly represented by triglyceride and cholesterol ester and waxes (table 3). Phospholipids only constituted 22.4 to $27.4 \%$ of the total lipid. There were significant differences between eggs and gonads, for total phospholipid $(p<0.05)$ and for cholesterol ester + waxes $(p<0.05)$. Considering latty acids (table 4), the relative proportions of Saturated Fatty 

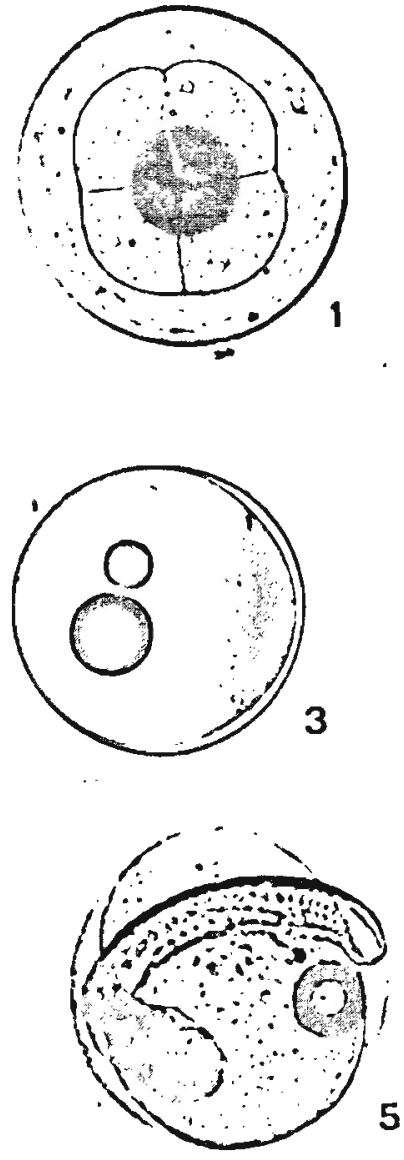
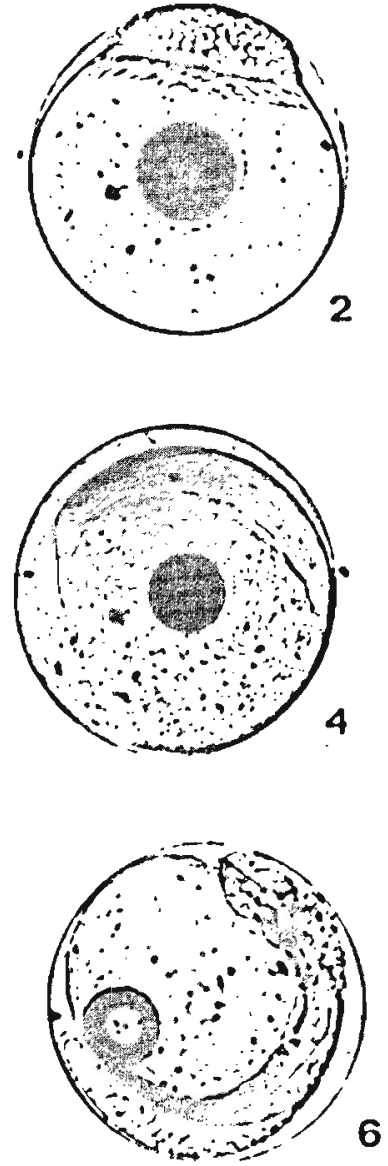

Figure 1. - Sea bass embryogencsis at $15 \pm 0.2^{\circ} \mathrm{C}$. 1: Four cell-stage ( $30 \mathrm{~min})$; 2: morula $(8.20 \mathrm{hrs}) ; 3$ : beginning of gastrulation ( $24 \mathrm{hrs}$.); 4: beginning of neurulation ( $34 \mathrm{hrs}$ ) ; 5: embryo ( 45 hrs.); 6: the heart beats ( $74 \mathrm{hrs}$ ); 7: hatching (115 hrs.).
Table 1. - Stages of embryo development of sea bass at 13,15 and $17^{\circ} \mathrm{C}$ (hour).

\begin{tabular}{lccc}
\hline \multirow{2}{*}{ Egg stage } & \multicolumn{3}{c}{ Temperature $\left({ }^{\circ} \mathrm{C}\right)$} \\
\cline { 2 - 4 } & 13 & 15 & 17 \\
\hline Morula & 8.20 & 7.20 & 5.30 \\
Beginning of gastrulation & 24 & 19 & 16.40 \\
Beginning of neurulation & 34 & 24 & 21 \\
Embrjo in the half circumference & 45 & 31 & 24 \\
Heart beats & 74 & 48 & 51 \\
$50 \%$ hatching & $115 \pm 5 \mathrm{~h}$ & $81 \pm 3 \mathrm{~h}$ & $72 \pm 2 \mathrm{~h}$ \\
\hline
\end{tabular}

Acids (SFA) and Unsaturated Fatty Acids (UNFA) were similar in both groups. The lower total lipid (\% DW) of gonads was the reason for lower SFA and UNFA levels when expressed as \% DIV $(p<0.05)$. Among UNFA, the groups analysed were the $n-7, n-9, n-6$ and $n-3$ groups. The $n-7$ and $n-6$ groups were slightly but not significantly lower in eggs while the $n-9(p<0.05)$ and especially $n-3$ groups $(p<0.01)$ were significantly higher in cggs.

The analysis of classes of phosphoaminolipids (table 5) indicated a strong predominance of the phosphatidylcholine and phosphatidyl ethanolamine. The 
Table 2. - Proximal composition of sea bass eggs at morula stage and fonads of wild fish caught during the spawning season. Viability is a measure of the quality of the egg batches used.

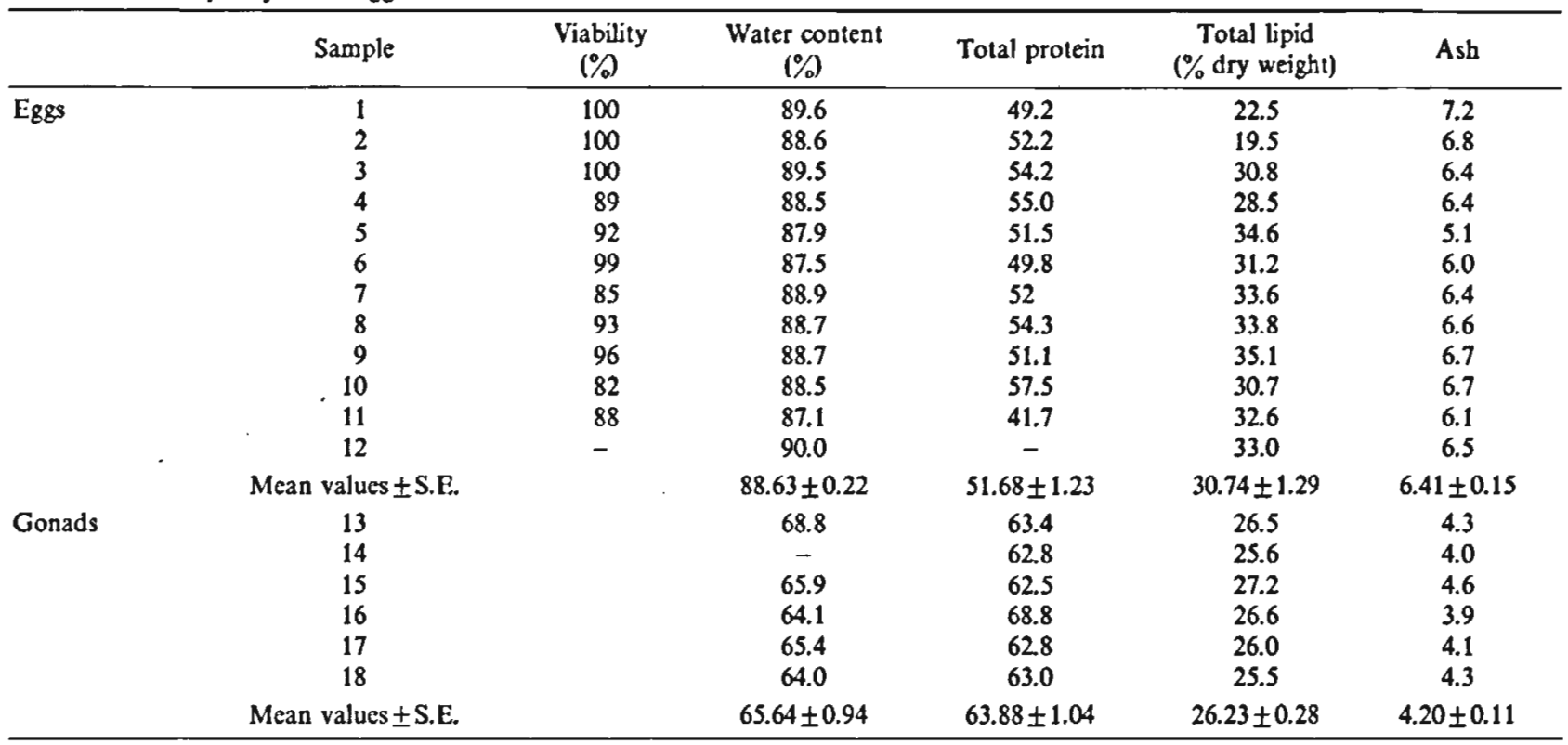

Table 3. - Lipid composition of sea bass eggs and gonads.

\begin{tabular}{|c|c|c|c|c|c|}
\hline & \multirow{2}{*}{ Sample } & \multirow{2}{*}{ Phospholipid } & Triglyceride & Cholesterol & Cholesterol ester + waxes \\
\hline & & & \multicolumn{3}{|c|}{ Total lipids (\%) } \\
\hline \multirow[t]{7}{*}{ Eggs } & 3 & 23.9 & 31.6 & 4.4 & 40.6 \\
\hline & 6 & 23 & 35.2 & 4.6 & 38.8 \\
\hline & 7 & 25.3 & 32.3 & 4.6 & 35.6 \\
\hline & 8 & 22.8 & 34.4 & 5.3 & 36.5 \\
\hline & 11 & 24.9 & 29.6 & 4.5 & 41.6 \\
\hline & 12 & 22.4 & 28.4 & 3.8 & 41.6 \\
\hline & Mean values \pm S.E. & $23.4 \pm 0.36$ & $32.87 \pm 0.86$ & $4.72 \pm 0.21$ & $38.73 \pm 0.77$ \\
\hline \multirow[t]{3}{*}{ Gonads } & 13 & 24.1 & 29.8 & 4.9 & 37.2 \\
\hline & 14 & 27.4 & 30.4 & 4.8 & 35.4 \\
\hline & 15 & 24.2 & 32.5 & 5.2 & 34.8 \\
\hline
\end{tabular}

levels were slightly higher in eggs for all the classes considered, except LPC, but only the PS levels were significantly lower in eggs $(p<0.01)$; the LPC ratio was significantly higher in eggs $(p<0.01)$. Some mincral levels differed: table 6 . Calcium and magnesium were more abundant in eggs $(p<0.01)$. Phosphorus was lower in eggs $(p<0.01)$.

\section{Relationship between several egg characteristics (table 7)}

The data were submitted to statistical Bravais Pearson test (Sokal and Rohlf, 1969) which revealed the main correlation at $p<0.05$. Positive correlations were found between egg diameter and egg dry weight $(r=<0.597)$ and between egg dry weight and percentage of deformities of newly hatched larvae $(r=0.558)$ and a negative correlation was found between egg dry weight and hatching percentage of viable eggs $(r=-0.551)$. No correlation was evident between temperature and egg diameter.

\section{DISCUSSION-CONCLUSION}

Most other studies of sea bass eggs give descriptions and information concerning incubation period similar 
Table 4. - Fatty acid composition (F.A.) of sea bass eggs and gonads.

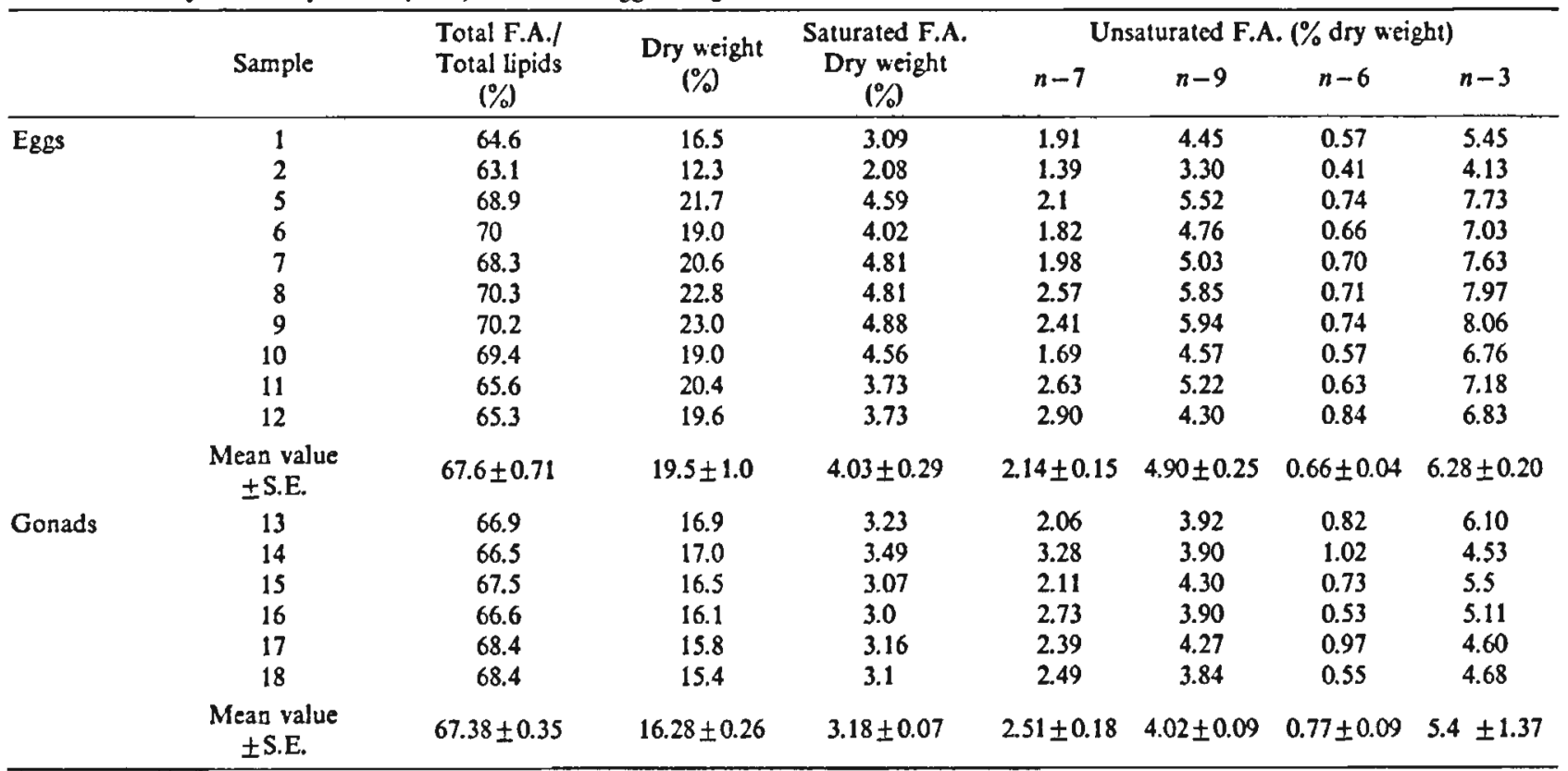

Table 5. - Lipid phosphorus content of sea bass eggs and gonads. The phosphorus contents of the various phosphatides are expressed as percentage of total lipid phosphorus. LPC, lysophosphatidylcholine; SPII, sphingomyelin; PC, phosphatidylcholine; PS, phosphatidylserine; PI, phosphatidylinositol; PE, phosphatidylethanolamine; DPG, diphosphatidylglycerol; AP, phosphatidic acid.

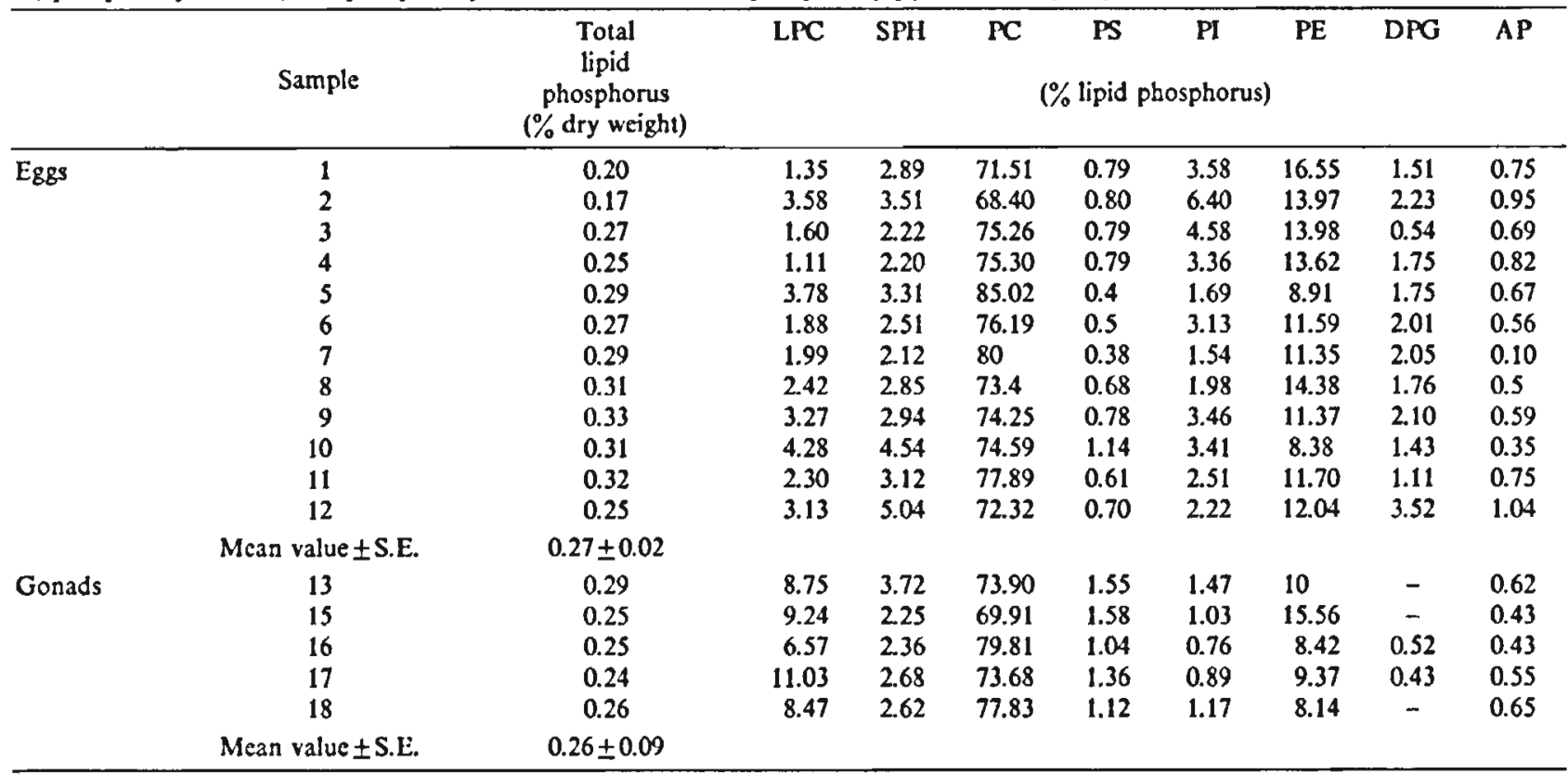

to ours for eggs incubated in large tanks. Small static incubators, both the incubation period (Marangos et al., 1986), and the hatching process are longer (Huelvan, 1982). The duration of fertilization and hatching processes as well as the number of abnormalitics of mitoses can be increased under stressful incubation conditions (Blaxter, 1969; Rosenthal and Alderdice, 1976; Hcmpcl, 1979; Kjorsvisk et al., 1984) (low oxygen levels, bacteria infections, mechanical shocks, etc.) or with eggs of poor quality (Marangos et al., 1986). Thus it is not surprising to find differences in the embryogenesis of eggs developed in very different incubation systems. However in general, egg development is not a major problem in the rearing of sea bass. According to Marangos et al. (1986), more than $50 \%$ of the viable eggs hatch at temperatures ranging from 8 to $20^{\circ} \mathrm{C}$ at salinity $47 \times 10^{-3}$, from 8 to $14^{\circ} \mathrm{C}$ and salinitics from 29 to $47 \times 10^{-3}$. Long incubation 
Table 6. - Mineral composition of sea bass eggs and gonads.

\begin{tabular}{|c|c|c|c|c|c|c|c|c|}
\hline & Sample & Calcium & Phosphorus & $\begin{array}{c}\text { Magnesium } \\
10^{-6} \text { dry weight }\end{array}$ & Iron & Zinc & Copper & Manganese \\
\hline \multirow[t]{10}{*}{$\overline{\mathrm{Eggs}}$} & 1 & 1500 & 9400 & 1060 & 90 & 110 & 19 & $\bullet$ \\
\hline & 2 & 2520 & 9400 & 709 & 68 & 145 & 34 & $*$ \\
\hline & 4 & 1590 & 9700 & 1071 & 53 & 159 & 27 & * \\
\hline & 5 & 815 & 7845 & 6616 & 57 & 137 & 18 & * \\
\hline & 6 & 1260 & 7885 & 907 & 81 & 134 & 16 & • \\
\hline & 9 & 784 & 2500 & 914 & 52 & 103 & 17 & * \\
\hline & 10 & 2144 & 9730 & 658 & 135 & 99 & 18 & * \\
\hline & 11 & 876 & 8180 & 785 & 74 & 140 & 17 & * \\
\hline & 12 & 1670 & 6630 & 979 & 63 & 95 & 21 & $*$ \\
\hline & Mean values & 1270 & 7709 & 878 & 63 & 137 & 20 & \\
\hline & 18 & 218 & 11300 & 380 & 58 & 127 & so & * \\
\hline & Mean values & 246 & 11380 & 388 & 58.4 & 136 & 30.4 & \\
\hline
\end{tabular}

not detectable.

Table 7. - Characteristics of sea bass eggs. Temperature = rearing temperature of broodstock at spawning. Diameter ( $\pm 0.01 \mathrm{~mm}) \mathrm{S} . \mathrm{E}$.

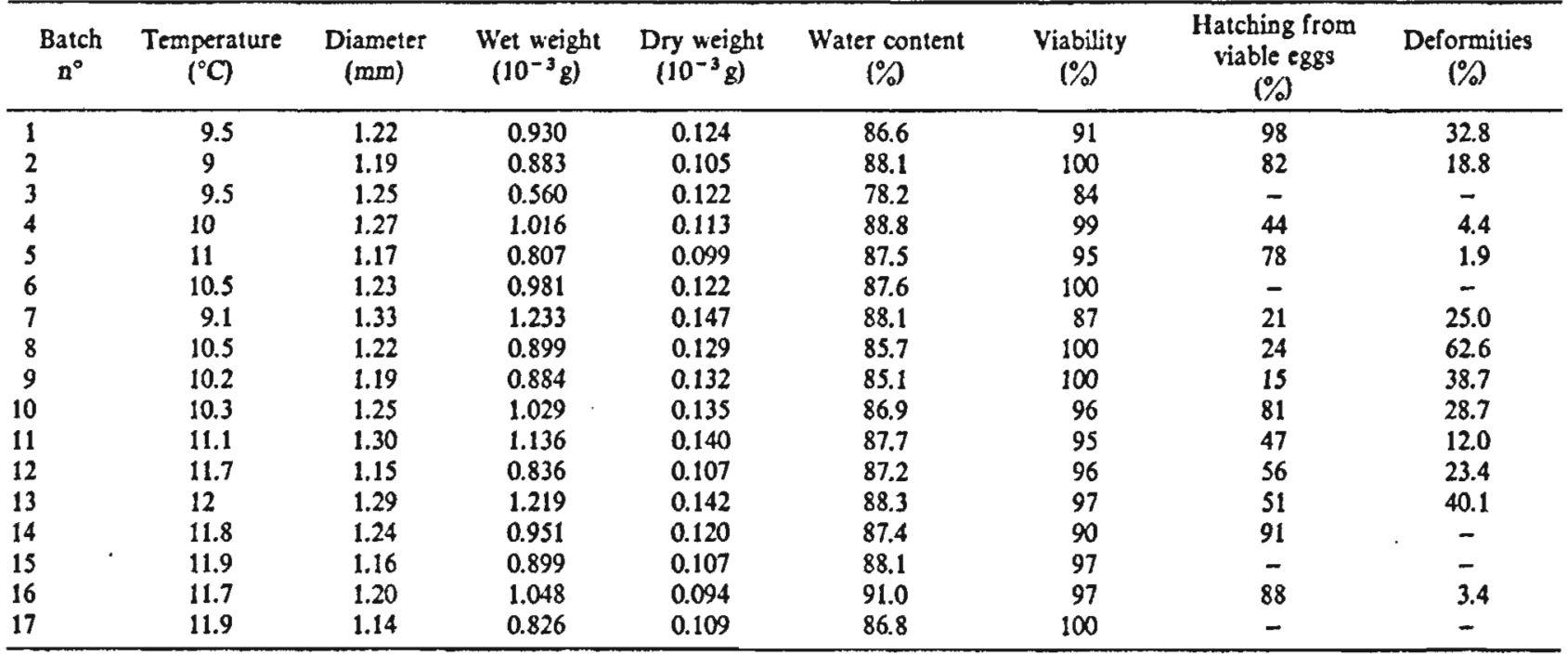

periods are inadvisable as bacterial contamination can become a problem, especially when high densities of incubation are practised. In such a situation, it is necessary to change the incubator water regularly as in the case of halibut (Kjorsvisk et al., 1984). Incubation at $13-17^{\circ} \mathrm{C}$ and salinity $35-38 \times 10^{-3}$ gave satisfactory results, with hatching percentages always close to $80-90 \%$ and low percentages of deformity.

Eggs diameters vary from place to place. In Brittany, values from 1.07 to 1.32 were obtained (Devauchelle, 1986). Along the Mediterranean coast, the eggs are smaller (Villani, 1974; Barnabé, 1976): 1.02 - 1.296, while the largest eggs are obtained from the North Sea, up to 1.386 (Kennedy and Fitzmaurice, 1972). It was suggested by Ware (1975) that egg diameter may be related to water temperature and/or food availability. This has not been demonstrated experimentally but observations (Devauchelle, 1980) suggest that eggs spawned from normal spawning season broodstock maintained at constant temperature are smaller than those from broodstock submitted to the natural thermal cycles especially low winter temperatures.

Until now, no clear relationship has been found between the egg diameter and the larval performance, although, such a relationship has often been discussed 
for marine fish, salmonids and freshwater fish (Blaxter, 1969; Hempel, 1979). Thus egg diameter still cannot be considered as an indicator of larval quality. Rana (1987) considered that the egg size had little influence on the onset of feeding but could modify the resistance of fish to the stressful environment of the rearing tanks; the egg dry weight which is correlated with both diameter and hatching percentage might be a better indicator of quality. Similar observations could be made for total proteins and total lipids. Craik and Harvey (1984) demonstrated that the wet weight, dry weight, lipid or protein contents were positively linked to the rainbow trout survival before first feeding. The aim of this study was not to prove a such relationship, but to examine how the egg composition might be used in further research in sea bass broodstock management and larval rearing. Such data may be useful in the definition of quality, for commercial hatcheries and in the improvement of larval nutrition. Compared to turbot (Scophthalmus maximus) and sole (Solea solea) which are also involved in European aquaculture projects sea bass, has two peculiarities: egg protein levels are higher and egg lipid levels lower (Devauchelle et al., 1987, 1988). Moreover phospholipids, which represent around $40 \%$ of the total lipid in 1]atfish, only reach 20 to $24 \%$ in sea bass eggs. In addition, the level of total lipid secms to be affected by the rearing conditions. The composition of eggs spawned during the normal season is closer to that of gonads, while eggs spawned outside the normal spawning season contain more lipid. Since, during gametogenesis, the oocytes first accumulate lipid, then protein (Caporiccio, 1976), the stage of maturity of the gonads cannot explain such differences. Rather the relative ratio of lipid to protein seems to be inadequate in the spawners food. Since in captivity physical activity is low, the fish do not metabolize their reserves and probably accumulate more lipids than in the wild. Previous work has shown a harmful effect on the larval rearing of too high lipid reserves in eggs of molluscs (Gallager and Mann, 1986). For fish, Luquet and Watanabe (1986) pointed out controversial results of the literature concerning the effects of food energy and egg quality. As long as these relations will remain vague, we think that the biochemical composition might be a good quality criterion. On the other hand, such criteria can also be obtained by physical shocks as already tested by Devauchelle (1980) and Divanach (1985).

The analysis of inorganic and amino-phospholipid composition showed large differences between eggs and gonads. The stage of maturity of the gonads and eggs have to be taken in account here. It is well known that changes in levels of water and ions occur during maturation, ovulation and fertilization (Holliday, 1969; Potts and Rudy, 1969; Davenport et al., 1981; Craik and Harvcy, 1987). Embryogenesis is also a period of high variation in phospholipid content. Since the ratio of different aminophospholipids might change very easily depending on the precise stage of eggs considered, the differences in table 5 have to be treated with caution.

The problems of ability of eggs to develop in larvae with high growth or survival rates are now important for the aquaculture development. As emphasized by Billard (1987), many practical problems raised in these areas (biology of gametes, fertilization, embryogenesis, hatching, chorion fragility...) have been neglected in studies of fish reproductive physiology. We hope that these field work will soon be more attractive to scientists.

\section{Acknonledgements}

This work was made with the technical assistance of two IFREMER stations: "Aquaculture and Fisheries", Brest and MEREA, Palavas-les-Flots. Let us particularly thank J. C. Alexandre, J. F. Bouget, Y. Cladas, Y. Letty, M. Suquet.

\section{REFERENCES}

Barnabe G., 1976. Rapport technique sur la ponte induite et l'élevage des larves du loup (Dicentrarchus labrax) et de la daurade (Sparus aurata). Cons. Gén. Pèches Méditer., 55, 63-116.

Billard R., 1987. Fish reproductive physioly, fish culture and fisheries: concluding remarks. In: Proceedings of the third international symposium on reproductive physiology of fish. St John's, Newfoundland, Canada. August 2.7 1987, D. R. Idler, L. W. Crim, J. M. Walsh Eds., 316-318.

Blaxter J. H. S., 1969. Development: eggs and larvae. Fish Physiology, 3. Academic Press, New York, 178-271.
Caporiccio B., 1976. Étude ultrastructurale et cytochimique de l'ovogenèse du loup (Dicentrarchus labrax L.). Thèse dr. $3^{\circ}$ cycle, Univ. Sci. Tech. Langucdoc, Montpellier, $87 \mathrm{p}$.

Craik J. C. A., S. M. Harvey, 1984. Egg quality in rainbow trout: the relation between egg viability, selected aspects of egg composition and time of stripping. Aquaculture, 40, 115-134.

Craik J. L. A., S. M. Harvey, 1987. The causes of buyoancy in eggs of marine teleosts. J. Mar. Biol. Ass. U.K, 67, 169-182.

Davenport J., S. Lonning, E, Kjorsvik, 1981. Osmotic and structural changes during early development of eggs and larvae of the cod (Gadus morhua L.). J. Fish Biol., 19, 317.331. 
Devauchelle N., 1980. Étude expérimentale sur la reproduction, les cuffs et les larves de bar (Dicentrarchus labrax), daurade (Sparus aurata), mulet (Liza ramada), rouget (Mullus surmuletus), sole (Solea solea) et turbot (Scophthalmus maximus). Thẻse dr. $3^{\circ} \mathrm{cycle}$, Univ. Brest, $196 \mathrm{p}$.

-, 1986. Ponte en captivité et incubation de quatre poissons marins élevés en Europe. Conférence de formation MEDRAP/FAO, Production contrôlée d'alevins en Europe, Zadar/Pula, Yougoslavie, 10-28 lévrier 1986, $50 \mathrm{p}$.

Devauchelle N., Y. Letty, M. Quéré, 1986. Experimental units for incubation and larval rearing with special references to four marine fish species. Aquaculture, 58, 297 304.

Devauchelle N., J. C. Alexandre, N. Le Corre, Y. Letty, 1987. Spawning of sole (Solea solea) in captivity. Aquaculture, 66, 125-147.

,- 1988 . Spawning of turbot (Scophthalmus maximus) in captivity. Aquaculture, 69, 159-184.

Divanach P., 1985. Contribution à la connaissance de la biologie et de l'élevage de six Sparidés méditerranéens : Sparus aurata, Diplodus sargus, Diplodus tulgaris, Diplodus annularis, Litognat hus mormyrus, Puntazzo puntazzo (Poissons Téléostéenns). Thèse dr. État, Univ. Sci. Tech. Languedoc, Montpellier, $479 \mathrm{p}$.

Gallager S. M., R. Mann, 1986. Growth and survival of Larvae of (Mercenaria mercenaria) and (Crassostrea tirginica Gmelin) relative to broodstock conditioning and lipid content of eggs. Aquaculture, 56, 105-121.

Hempel G., 1979. Early life of marine fish. The egg stage. Library of Congress, $71 \mathrm{p}$.

Holliday F. G. T., 1969. The effects of salinity on the eggs and larvac of telcosts. In: Fish Physiology, I. W. S. Hoar, D. J. Randall Eds., Academic Press, New York, 293311.

Huelvan S., 1982. Étude de la résistance au froid des ceufs de bar (Dicentrarchus labrax L.) et de sole (Solea tulgaris L.). Rapp. D.E.A. océan. biol., Univ. Brest, $24 \mathrm{p}$.

Kennedy M., P. Fitzmaurice, 1972. The biology of the bass, (Dicentrarchus labrax), in Irish waters. J. Mar. Biol. Ass. U.K., 52, 557-597.

Kjorsvik E., A. Stene, S. Vonning, 1984. Morphological, physiological and genetical studies of egg quality in Cod (Gadus morhua L.). Floderigen rapp., 1, 67-86.

Luquet P., T. Watanabe, 1986. Interaction "nutritionreproduction" in fish. Fish Physiol. Biochem., 2, 121-129.

Marangos C., M. Yagi, H. J. Ceccaldi, 1986. The role of temperature and salinity on hatching rate and morphogenesis during the embryo development in Sea bass (Dicentrarchus labrax L., 1758) (Pisces, Teleostei, Serranidae). Aquaculture, 54, 287-300.

Potts W. T. W., P. P. Rudy, 1969. Water Balance in the eggs of the atlantic salmon (Salmo salar). J. Exp. Biol., 50, 223-237.

Rana K. J., 1987. Influence of egg size on the growth, onset of fecding, point of no return, and survival of unfed Oreochromis Mosambicus fry. Aquaculture, 46, 119-131.

Rosenthal H., D. F. Alderdice, 1976. Sublethal effects of environmental stressous, nalural and pollutional, on marine fish eggs and larvae. J. Fish. Res. Board Can., 33, 2047-2067.

Sokal R., F. J. Rohlf, 1969. Biometry: the principales and practice of statistics in biological research, $276 \mathrm{p}$.

Villani P., 1974. Ponte induite et élevage des poissons marins dans les conditions de laboratoire. In: The Early life history of fish, J. H. S. Blaxter Ed., Springer Verlag. 117-132.

Ware D. M., 1975. Relation between egg size, growth and natural mortality of larval fish. J. Fish. Res. Board Can., 32, 2503-2512. 